\title{
PENERAPAN MODEL PEMBELAJARANQUANTUM TEACHING UNTUK MENINGKATKAN HASIL BELAJAR MATEMATIKA PADA MATERI FPB KELAS IV SD NEGERI SINDANGWASA KECAMATAN PALASAH KABUPATEN MAJALENGKA
}

Yeni Dwi Kurino ${ }^{1}$ )

Yenidwi_kurino@yahoo.com

\begin{abstract}
ABSTRAK
Penelitian ini dilatarbelakangi oleh kurangnya hasil belajar siswa dalam pelajaran matematika SD, khusunya yang berkaitan dengan materi belajar FPB yang berada di Kelas IV SD. Penelitian ini bertujuan untuk meningkatkan hasil belajar siswa dalam pelajaran matematika SD demngan menggunakan model pembelajaran Quantum Teaching. Dimana kerangka Quantum Teaching dikenal dengan istilah TANDUR, Yaitu : Tumbuhan (T), Alami (A), Namai (N), Demontrasikan (D), ulangi (U), dan Rayakan (R).Penelitian ini merupakan Penelitian Tindakan Kelas. Populasi dalam penelitian ini adalah siswa keals IV SD yang tedapat di Kabupaten Majalengka. Sampel penelitian ini adalah siswa kelas IV SD N Sindangwasa Kecamatan Palasah Kabupaten Majalengka.Hasil penelitian menunjukkan bahwa terdapat peningkatan dari siklus 1, siklus II dan siklus III. Penerapan model Quantum Teaching pada materi FPB dapat meningkatkan hasil belajar siswa kelas IV SD Negeri Sindangwasa Kecamatan Palasah kabupaten Majalengka. Pada siklus 1 memperoleh nilai rata-rata 68,88 dengan ketuntasan secara klasikal 65,62\% yaitu 21 siswa katagori tuntas, 6 siswa $(18,75 \%)$ dikatagorikan belum tuntas dan 5 siswa $(15,62 \%)$ belum memenuhi kriteria penilaian karna tidak hadir, pada siklus ke II sudah mengalami peningkatan dengan nilai rata-rata 74, dengan ketuntasan secara klasikal 84,37 yaitu 27 siswa katagori tuntas, 3 siswa $(9,38 \%)$ belum tuntas dan 2 siswa (6,25\%) belum memenuhi kriteria penelaian karna tidak hadir atau sakit, sedangkan pada siklus III juga sudah mengalami peningkatan dibandingkan pada siklus II dengan nilai rata-rata 86,3 dengan ketuntasan secara klasikal $(87,5 \%)$ yaitu 28 siswa dalam katagori tuntas, 2 siswa $(6,25 \%)$ belum tuntas dan 2 siswa $(6,25 \%)$ belum memenuhi kriteria penilaian karna tidak mengikuti proses penilaian.
\end{abstract}

Kata kunci: Model Pembelajaran Quantum Teaching dan Hasil Belajar

\footnotetext{
${ }^{1}$ Penulis adalah dosen tetap Prodi PGSD Fakultas Pendidikan Dasar dan Menengah Universitas Majalengka
} 


\section{PENDAHULUAN}

Dalam Kurikulum Tingkat Satuan Pendidikan (KTSP) dinyatakan bahwa mata pelajaran matematika perlu diberikan kepada semua siswa mulai dari sekolah dasar untuk membekali siswa kemampuan berpikir logis, analitis, sistematis, kritis, dan kreatif, serta kemampuan bekerjasama (Depdiknas, 2006). Adapun tujuan mata pelajaran matematika untuk semua jenjang pendidikan dasar dan menengah adalah agar siswa mampu:1.

Memahami konsep matematika, menjelaskan keterkaitan antarkonsep, dan mengaplikasikan konsep atau algoritma secara luwes, akurat, efisien, dan tepat dalam pemecahan masalah.2.Menggunakan penalaran pada pola dan sifat, melakukan manipulasi matematika dalam membuat generalisasi, menyusun bukti, atau menjelaskan gagasan dan pernyataan matematika.3Memecahkan masalah yang meliputi kemampuan memahami masalah, merancang model matematika, menyelesaikan model, dan menafsirkan solusi yang diperoleh.4.Mengkomunikasikan gagasan dengan simbol, tabel, diagram, atau media lain untuk memperjelas keadaan atau masalah.5 .Memiliki sikap menghargai kegunaan matematika dalam kehidupan, yaitu rasa ingin tahu, perhatian, dan minat dalam mempelajari matematika, serta sikap ulet dan percaya diri dalam pemecahan masalah (Depdiknas, 2006).

Pembelajaran matematika di Sekolah Dasar yang menekankan keterampilan diatas memerlukan kegiatan praktis yang dapat mengarahkan pada pemahaman konsep matematika. Agar harapan tersebut tercapai maka dalam proses pembelajarannya guru harus mampu menciptakan dan mempersiapkan siswa dalam menggunakan matematika dan pola pikir matematika dalam kehidupan sehari-hari. Pembelajaran matematika di Sekolah Dasar harus terencana dan terprogram sesuai dengan tingkat dan perkembangan anak secara optimal, sehingga diharapkan dapat membantu proses pembelajaran matematika di Sekolah.

Dalam kegiatan pembelajaran seorang guru mengharapkan kondisi pembelajaran yang kondusif, artinya siswa merasa nyaman dalam belajarnya, tidak merasa bosan, jauh dari ketakutan dan halhal lain yang bersifat negatif yang dapat menghambat terciptanya suatu pembelajaran yang kondusif, oleh karena itu berbagai upaya yang dilakukan oleh guru agar setiap pembelajaran dilaksankan dengan multiarah. Dimana guru dan siswa, siswa dengan siswa yang lainnya saling berinteraksi untuk mencapai kondisi yang kondusif.

Diketahui bahwa dalam proses pembelajaran matematika siswa kelas IV SD Negeri Sindangwasa Kecamatan Palasah kabupaten Majalengka masih lemah dalam memahaminya. Sedangkan aktivitas yang melibatkan imajinasi, intuisi, dan seni, belum dikembangkan secara maksimal dalam pembelajaran matematika. Hal ini menyebabkan siswa sulit memahami konsep yang dipelajari, karena siswa hanya mendengar penjelasan guru, kemudian mengerjakan beberapa soal latihan tanpa terlibat dalam aktivitas pembelajaran yang menarik dan membangkitkan imajinasi anak.

Salah satu materi yang sulit dipahami siswa karena kecenderunganhanya mendengarkan dan mengerjakan latihan sehingga siswa jenuh dan membosankan adalah materi faktor persekutuan terbesar (FPB). Dari wawancara dengan guru tersebut juga diketahui bahwa para siswa masih sulit memahami materi FPB, terutama pada faktor persekutuan dan menentukan FPB tersebut, karena siswa masih sulit dalam perkalian.

Berdasarkan uraian di atas, penulis ingin melakukan penelitian dengan judul "Penerapan model PembelajaranQuantum Teaching Untuk Meningkatkan Hasil Belajar 
Siswa Pada Mata Pelajaran Matematikadikelas IV SD Negeri Sindangwasa Kecamatan Palasah kabupaten Majalengka.

\section{KAJIAN PUSTAKA}

\section{Hasil Belajar Matematika}

Beberapa ahli dalam dunia pendidikan memberikan definisi belajar Sudjana (2005: 5) menyatakan bahwa Hasil belajar siswa pada hakikatnya adalah perubahan tingkah laku dan sebagai umpan balik dalam upaya memperbaiki proses belajar mengajar. Tingkah laku sebagai hasil belajar dalam pengertian luas mencakup bidang kognitif, afektif dan psikomotorik.Sementara itu menurut Tirtonegoro (2001: 43) mengemukakan bahwa hasil belajar adalah penilaian hasil kegiatan belajar yang dinyatakan dalam bentuk angka, huruf maupun kalimat yang dapat mencerminkan hasil yang sudah dicapai oleh setiap siswa dalam periode tertentu. Hasil belajar sama artinya dengan prestasi belajar yaitu penguasaan pengetahuan atau keterampilan yang lazimnya ditujukan dengan nilai atau angka yang diberikan oleh guru atau pembimbing. Prestasi belajar dalam hal ini adalah hasil yang dicapai dari penguasaan pengetahuan atau keterampilan yang dikembangkan mata pelajaran sebagai suatu pengalaman yang ditunjukkan dengan nilai tes atau nilai angka yang diberikan oleh seorang guru.

Dengan demikian dapat disimpulkan secara umum pengertian hasil belajar yaitu bentuk perubahan tingkah laku secara menyeluruh (komprehensif) yang terdiri dari unsur kognitif, efektif, dan psikomotorik secara terpadu terhadap diri siswa setelah mengalami aktivitas belajar.

2. Indikator Hasil Belajar

Benyamin Bloom (Sudjana, 2010: 22-31) mengklasifikasikan kemampuan hasil belajar ke dalam tiga kategori, yaitu:
1. Ranah kognitif, meliputi kemampuan menyatakan kembali konsep atau prinsip yang telah dipelajari dan kemampuan intelektual. Taksonomi tujuan pembelajaran dalam kawasan kognitif menurut Bloom terdiri atas enam tingkatan yaitu: Pengetahuan (C1) ,Pemahaman (C2), Penerapan (C3), Analisis (C4), Sintesis (C5),Evaluasi (C6)

2. Ranah afektif, berkenaan dengan sikap dan nilai yang terdiri atas aspek penerimaan, tanggapan, penilaian, pengelolaan, dan penghayatan (karakterisasi). Taksonomi tujuan pengajaran pada kawasan afektif dikategorikan dalam lima jenis yaitu: Penerimaan, Tanggapan, Penilaian, Pengelolaan, Penghayatan (karakterisasi).

3. Ranah psikomotorik, mencakup kemampuan yang berupaketerampilan fisik (motorik) yang terdiri dari gerakan refleks, keterampilan gerakan dasar, kemampuan perseptual, ketepatan, keterampilan kompleks, serta ekspresif dan interperatif. Taksonomi pembelajaran terhadap ranah psikomotorik secara garis besar dibedakan kedalam 4 tahap, yaitu: Meniru, memanipulasi,pengalamiahan dan artikluasi.

Pada penelitian kali ini peneliti lebih menekankan pada hasil belajar siswa ranah kognitif tentang pemahaman.Pemahaman disini merupakan Kemampuan memahami instruksi dan menegaskanpengertian/makna ide atau konsep yang telah diajarkan baik dalam bentuk lisan, tertulis, maupun grafik atau diagram. Maka dapat disimpulkan bahwa pemahaman merupakan salah satu jenjang kemampuan dalam proses berpikir dimana siswa dituntut untuk memahami, yang berarti mengetahui tentang sesuatu hal dan dapat melihatnya dari beberapa segi. Pada tingkatan ini, selain hapal siswa juga 
harus memahami makna yang terkandung didalamnya. Ada beberapa indikator dalam pemahaman disini seperti yang tertulis diantaranya :Menerangkan,Menjelaskan, Menerjemahkan, Menguraikan ,Mengartikan ,Menyatakan kembali, Menafsirkan, Menginterpretasikan, Mendiskusikan, Menyeleksi, Mendeteksi, Melaporkan, Menduga, Mengelompokkan, Memberi contoh, Merangkum,Menganalogikan, Mengubah, Memperkirakan.

Dari penjelasan diatas dalam penelitian yang akan dilaksanakan, peneliti menggunakan beberapa saja indikator hasil belajar ranah kognitif tentang pemahaman yaitu menarik kesimpulan, menjelaskan, dan memberi contoh. Hal tersebut dilatarbelakangi karena pada siswa kelas IV di SDN sindangwasa, mereka masih kesulitan untuk belajar menarik kesimpulan dari sebuah peristiwa, menjelaskan kembali materi yang telah mereka pelajari serta dalam memberikan contoh.

\section{Tinjauan Tentang Quantum Teaching}

DePorter (dalam Nilandri, 2005 : 4) "Quantum Teaching diciptakan berdasarkan teori-teori belajar seperti Accelerated Learning (Lozanov), Multiple Intelligences (Gardner), Neuron-Linguistic Programming (Grinder dan Blander), Experiential Learning (Hahn), SocraticInquiry, Cooperative Learning, dan Element of Effective Intruction (Hunter)". Quantum Teaching yang pada mulanya merupakan badan ilmu pengetahuan dan metodelogi yang digunakan dalam rancangan, penyajian, dan fasilitas SuprCamp. Pengertian Supr Camp adalah sebuah program pelatihan dan pengembangan intensif bukan saja untuk kaum muda, melainkan juga untuk para mahasiswa tingkat lanjut".Pelatihan ini dilakukan di luar sekolah.

Quantum Teaching menurut pendapat DePorter (dalam Nilandri 2005:32) adalah sebagai berikut :
"Quantum Teaching adalah berbagai interaksi yang di dalam dan di sekitar momen belajar.Interaksi-interaksi ini mencakup unsur-unsur untuk belajar efektif yang mempengaruhi kesuksesan siswa. Pembelajaran yang menyingkirkan hambatan yang menghalangi proses kegiatan belajar dengan cara sengaja menggunakan musik/mewarnai lingkungan sekeliling, menyusun bahan pengajaran yang sesuai pengajaran yang efektif dan banyak mengaftifkan siswa".

\section{a. Model Quantum Teaching}

Quantum Teaching menurut pendapat DePorter (dalam Nilandri 2005:32) adalah sebagai berikut :

"Quantum Teaching adalah berbagai interaksi yang di dalam dan di sekitar momen belajar.Interaksi-interaksi ini mencakup unsur-unsur untuk belajar efektif yang mempengaruhi kesuksesan siswa. Pembelajaran yang menyingkirkan hambatan yang menghalangi proses kegiatan belajar dengan cara sengaja menggunakan musik/mewarnai lingkungan sekeliling, menyusun bahan pengajaran yang sesuai pengajaran yang efektif dan banyak mengaftifkan siswa".

Deporter (dalam Nilandri, $2: 10$ ) mengungkapkan : Kerangka Quantum Teaching dikenal dengan istilah TANDUR, Yaitu : Tumbuhan (T), Alami (A), Namai (N), Demontrasikan (D), ulangi (U), dan Rayakan (R). dalam proses belajar mengajar kerangka TANDUR sebagai berikut :

\section{a. Tumbuhkan}

Guru menumbuhkan minat belajar siswa dengan memuaskan. Tumbuh kesadaran "apa manfaatnya bagiku”, yaitu menyadari manfaat mempelajari suatu konsep bagi siswa.Untuk itu guru menjelaskan tujuan pembelajaran dan manfaatnya bagi siswa.

b. Alami 
Guru meminta menyelesaikan masalah nyata baik secara nyata, secara individu ataupun kelompok, dengan memanfaatkan sumber belajar/alat/bahan. Guru memberikan pengakuan atau penguatan

c. Namai

Setelah siswa mengalami tahapan kedua nyakni mengalami proses belajar sampai siswa menemukan suatu temuan baru, maka siswa dapat membantu guru bersama-sama menamai temuan baru tersebut apakah konsep, simbol, definisi, rumus, diskontruksikan, dari masalah yang telah diselesaikan siswa.

\section{d. Demonstrasi}

Guru memberikan kesempatan kepada siswa memperlihatkan bahwa mereka bisa melakukan atau menyelesaikan masalah-masalah baru yang senada dengan masalah yang telah dialaminya dengan kegiatan pembelajaran.

e. Ulangi

Guru bersama siswa merangkum materi yang telah dipelajari melalui tanya jawab guru menggiring siswa untuk dapat mengulangi materi yang telah dibahas. Melalui tahapan ulangi, guru mendapatkan umpan balik tentang kemajuan yang didapatkan siswa.

f. Rayakan

Guru harus memberikan penghargaan berupa pujian atau hadiah bagi siswa yang berhasil menunjukkan prestasi gemilang dan ini tidak boleh diabaikan oleh Guru. Pengakuan akan prestasi yang bagus akan memotivasi siswa untuk cenderung mempertahankan atau malah meningkatkan prestasinya. Penghargaan yang cepat dan tepat amat dibutuhkan siswa sebagai pengakuan atas kemampuannya.

\section{Instrumen dan Teknik Pengumpulan Data}

a. Tes hasil belajar
Lembar tes diberikan dan dikerjakan oleh siswa setiap akhir siklus dan digunakan untuk mengetahui pemahaman konsep siswa. Lembar tes hasil belajar tersebut dilakukan untuk mengetahui ketuntasan belajar siswa.Soal Tes difungsikan untuk mengetahui tingkat pemahaman siswa setelah mengikuti kegiatan pembelajaran juga dapatdigunakan untuk mengukur prestasi keberhasilan belajar siswa. Soal-soal disusun sesuai dengan indikator pembelajaran.Serta komposisi dalam konstruksinya disesuaikan dengan jenis kegiatan belajar pada tiap tindakan.

b. Lembaran Observasi

Observasi merupakan bentuk pengamatan objek pada situasi yang diteliti. Observasi pada penelitian tindakan kelas ini berfungsi untuk mendokumentasikan pengaruh tindakan yang dilaksanakan pada tindakan terkait ke tindakan berikutnya sebagai dasar refleksi yang akan dilakukan pada putaran siklus berikutnya. Lembar panduan observasi digunakan untuk mengumpulkan data aktivitas belajar siswa selama pembelajaran.

c. Lembar Kerja Siswa

Lembar Kerja Siswa (LKS) berfungsi untuk memberikan panduan kepada siswa dalam melakukan kegiatan belajar mandiri, sehingga mendukung prinsip pembelajaran matematika sebagai "As Human Activity".Melalui Lembar Kerja Siswa (LKS) siswa diharapkan supaya menjadi lebih aktif melakukan belajar (Doing Math) dan mengkonstruksi pemahaman konsep.Penggunaan Lembar Kerja Siswa (LKS) juga bermanfaat untuk melihat hasil kerja siswa dalam penelitian.Data dari Lembar Kerja Siswa (LKS) digunakan sebagai salah satu patokan untuk merancang dan melaksanakan tindakan pembelajaran selanjutnya. 


\section{Teknik Analisis Data}

Setelah semua kegiatan pengumpulan data selesai dilaksanakan, maka langkah selanjutnya adalah menganalisis data yang sudah yang sudah diperoleh selama penelitian. Data pengamatan dianalisis dengan menggunakan teknik deskriptif, sedangkan data yang dihasilkan dari tes dianalisis dengan menggunakan teknik statistik yaitu dengan menggunakan rumus persentase. Data penelitian tersebut adalah sebagai berikut:

\section{Siswa}

\section{a. Tes Ketuntasan Hasil Belajar}

Untuk mengetahui ketuntasan

hasil belajar siswaselama pembelajaran

berlangsung, digunakan rumus

persentase:

$$
P=\frac{\text { Banyak Siswa Yang Tuntas }}{\text { Keseluruhan Siswa }} \times 100 \%
$$

Keterangan :

$\mathrm{P}=$ persentase keterlaksanaan tahapan pembelajaran.

\section{Metode Penelitian}

Metode penelitian yang dilakukan penulis adalah metode Penelitian Tindakan
Kelas (classroom action research) yang mengacu kepada tindakan guru ketika melaksanakan pembelajaran sebagai upaya untuk memperbaiki kegiatan pembelajaran yang telah dilaksanakan. Hal ini sesuai dengan pernyataan Suharjono (Arikunto, 2006:58) yang mengemukakan bahwa "penelitian tindakan kelas adalah penelitian tindakan yang dilakukan di kelas dengan tujuan memperbaiki/meningkatkan mutu praktik belajar".Tujuan dilakukannya penelitian tindakan kelas adalah untuk : 1) peningkatan dan perbaikan praktek pembelajaran yang seharusnya dilakukan oleh guru. 2) perbaikan dan peningkatan layanan professional guru dalam menangani proses belajar mengajar. 3) terwujudnya proses latihan dalam jabatan selama proses penelitian berlangsung.

\section{Desain Penelitian}

Desain penelitian yang dilakukan oleh peneliti yaitu model siklus. Model siklus yang digunakan yaitu model menurut Kemis dan Mc.Taggart (Suyanto, 1997 : 16) yaitu terdiri dari empat komponen yaitu :

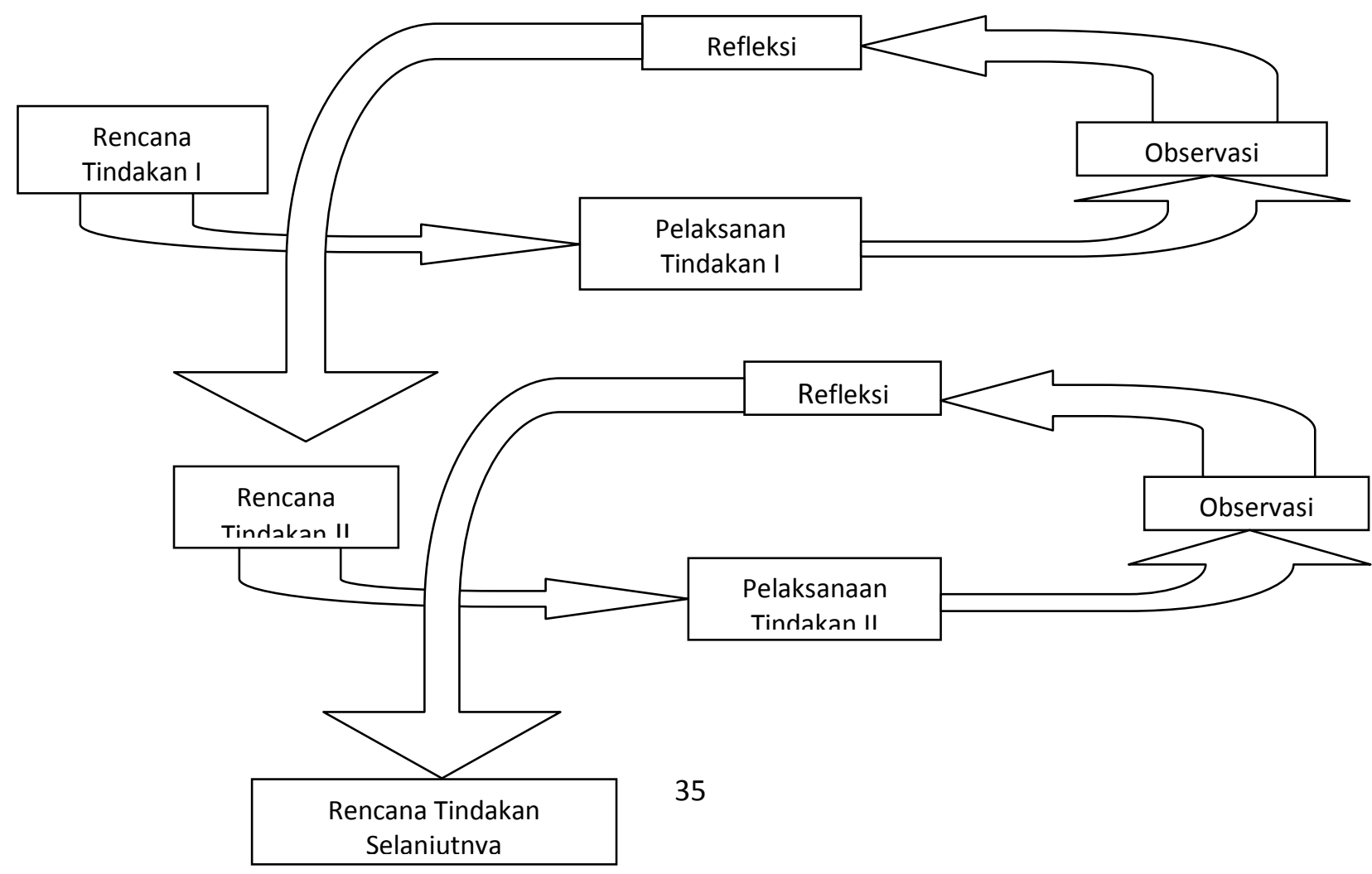


Gambar 3.1

Alur Penelitian Tindakan Kelas(PTK)

(Kasbolah, 1998 : 70).

HASIL PENELITIAN DAN PEMBAHASAN

\section{Hasil Penelitian \\ Siklus I}

Proses pembelajaran pada siklus I terdiri dari empat tahap yaitu perencanaan, pelaksanaan, observasi, dan refleksi.

\section{a. Perencanaan (Planning)}

Pada tahap ini dilakukan kegiatan identifikasi masalah dan analisa masalah penyebab timbulnya masalah yang terdapat pada proses pembelajaran sebelum tindakan kelas dilakukan. Pemecahan masalah yang diambil adalah dengan menggunakan model Quatum Teaching pada proses pembelajaran. Langkah yang dilakukan selanjutnya adalah dengan membuat Rencana Pelaksanaan Pembelajaran (RPP) yang mengacu pada pendekatan model Quatum Teaching. Guru juga mempersiapkan Lembar Kerja Siswa (LKS) dan lembar observasi aktivitas siswa.

\section{b. Pelaksanaan (acting)}

Kegiatan pembelajaran dengan menggunakan model Quatum Teaching dilaksanakan di kelas IV SD NegeriSindangwasa Kecamatan Palasah kabupaten Majalengka dengan jumlah siswa 32 orang. Permasalahan yang diberikan yaitu tentang Faktor Persekutuan Terbesar (FPB). Pertemuan pertama, guru telah mempersiapkan materi pembelajaran dengan beberapa media belajar siswa atau lembaran kerja siswa (LKS) sesuai dengan RPP yang telah disusun. Guru menjelaskan materi faktor persekutuan terbesar (FPB) kepada Siswa dengan seksama.

Untuk mengetahui kemampuan Siswa, guru mengelompokkan Siswa dengan jumlah setiap kelompok adalah 5-6 siswa. Pengelompokan siswa tersebut diatur sesuai dengan nomor urut absen. Setelah siswa dikelompokkan, maka guru membagikan soal kepada siswa dan siswa diwajibkan untuk menyelesaikan soal tersebut secara bersama-sama. Setelah 20 menit kemudian guru memberikan waktu kepada siswa tiap kelompok untuk menampilkan hasil kerjasama di depan kelas sambil mengadakan tanya jawab kepada siswa, kemudian jawab siswa dievaluasi oleh guru untuk mengetahui pengetahuan siswa mengenai materi Faktor Persekutuan Terbesar (FPB).

\section{c. Pengamatan/observasi}

Hasil pengamatan pada siklus I sebagai berikut.

1). Data hasil belajar siswa

Penilaian hasil belajar pada siklus I dilakukan melalui tes hasil belajar secara tertulis dan dilaksanakan setelah pembelajaran. Hasil belajar siswa dapat dilihat pada tabel 4.1berikut :

Tabel 4.1

Hasil tes belajar siswa pada siklus I

\begin{tabular}{|c|l|c|c|}
\hline No & \multicolumn{1}{|c|}{ Siswa } & Nilai & Katagori \\
\hline 1 & Siswa 1 & 80 & Tuntas \\
\hline 2 & Siswa 2 & 70 & Tuntas \\
\hline
\end{tabular}




\begin{tabular}{|c|c|c|c|}
\hline No & Siswa & Nilai & Katagori \\
\hline 3 & Siswa 3 & Sakit & - \\
\hline 4 & Siswa 4 & 70 & Tuntas \\
\hline 5 & Siswa 5 & 70 & Tuntas \\
\hline 6 & Siswa 6 & 60 & Belum Tuntas \\
\hline 7 & Siswa 7 & Sakit & - \\
\hline 8 & Siswa 8 & 60 & Belum Tuntas \\
\hline 9 & Siswa 9 & 80 & Tuntas \\
\hline 10 & Siswa 10 & 70 & Tuntas \\
\hline 11 & Siswa 11 & 60 & Belum Tuntas \\
\hline 12 & Siswa 12 & 60 & Belum Tuntas \\
\hline 13 & Siswa 13 & 70 & Tuntas \\
\hline 14 & Siswa 14 & 70 & Tuntas \\
\hline 15 & Siswa 15 & 80 & Tuntas \\
\hline 16 & Siswa 16 & 60 & Belum Tuntas \\
\hline 17 & Siswa 17 & 65 & Tuntas \\
\hline 18 & Siswa 18 & 70 & Tuntas \\
\hline 19 & Siswa 19 & 65 & Tuntas \\
\hline 20 & Siswa 20 & 70 & Tuntas \\
\hline 21 & Siswa 21 & 80 & Tuntas \\
\hline 22 & Siswa 22 & 75 & Tuntas \\
\hline 23 & Siswa 23 & 70 & Tuntas \\
\hline 24 & Siswa 24 & 70 & Tuntas \\
\hline 25 & Siswa 25 & 80 & Tuntas \\
\hline 26 & Siswa 26 & Alfa & - \\
\hline 27 & Siswa 27 & 65 & Tuntas \\
\hline 28 & Siswa 28 & 65 & Tuntas \\
\hline 29 & Siswa 29 & Sakit & - \\
\hline 30 & Siswa 30 & 65 & Tuntas \\
\hline 31 & Siswa 31 & 60 & Belum Tuntas \\
\hline 32 & Siswa 32 & Izin & - \\
\hline \multicolumn{2}{|r|}{ Jumlah } & 1860 & \\
\hline & Rata-rata & 68,88 & \\
\hline
\end{tabular}

Pada pembelajaran siklus I secara klasikal perolehan rata-rata hasil belajar siswaadalah sebesar 68,88 yaitu dengan ketuntasan belajar siswa secara klasikal $65,62 \%$ yaitu 21 orang siswa dalam katagori tuntas, sedangkan yang belum mencapai batas ketuntasan individual sebanyak 6 orang siswa atau $18,75 \%$ dan 5 orang siswa $(15,62 \%)$ dikatakan belum memenuhi kriteria penilaian oleh peneliti karena kelima siswa tersebut tidak mengikuti proses pembelajaran.

\section{d. Refleksi}

Berdasarkan hasil observasi pada pembelajaran siklus I, Pada 
pembelajaran siklus I secara klasikal perolehan rata-rata hasil belajar siswa adalah sebesar 68,88 yaitu dengan ketuntasan belajar siswa secara klasikal $65,62 \%$ yaitu 21 orang siswa dalam katagori tuntas, sedangkan yang belum mencapai batas ketuntasan individual sebanyak 6 orang siswa atau $18,75 \%$ dan 5 orang siswa $(15,62 \%)$ dikatakan belum memenuhi kriteria penilaian oleh peneliti karena kelima siswa tersebut tidak mengikuti proses pembelajaran. Berdasarkan refleksi siklus I, maka pembelajaran siklus I belum terpenuhi dan peneliti perlu melanjutkannya pada siklus II.

\section{Siklus II}

Proses pembelajaran pada siklus II terdiri dari 4 tahap yaitu perencanaan, pelaksanaan, observasi dan refleksi.

\section{a. Perencanaan (Planning)}

Berdasarkan refleksi pada siklus I, Pada siklus II dilakukan perbaikanperbaikan agar aktivitas dan hasil belsajar siswa dapat meningkat dengan melakukan identifikasi masalah yang dapat mempengaruhi keterlambatan siswa untuk memahami materi. Langkah yang dilakukan selanjutnya adalah dengan membuat dan merevisi Rencana Pelaksanaan Pembelajaran (RPP) yang mengacu pada pendekatan model Quatum Teaching. Guru juga mempersiapkan media pembelajaran yang unik, menarik dan lucu seperti kelereng warna-warni, Lembar Kerja Siswa (LKS), alat evaluasi siswa, lembar observasi aktivitas siswa.

\section{b. Pelaksanaan (acting)}

Kegiatan pembelajaran dengan menggunakan model Quatum Teaching dilaksanakan di kelas IV SD NegeriSindangwasa Kecamatan Palasah kabupaten Majalengkadengan jumlah siswa 32 orang. Guru mempersiapkan materi pembelajaran dengan beberapa media belajar siswa dan lembaran kerja siswa (LKS) sesuai dengan RPP yang telah disusun.

Guru menjelaskan materi FPB dengan cara pohon faktor kepada Siswa dengan seksama dan untuk mengetahui kemampuan siswa terhadap materi yang sebelumnya telah diberikan pada siklus I, guru memberikan pertanyaan kepada beberapa siswa secara random, kemudian mengelompokkan siswa dengan jumlah setiap kelompok sebanyak 5-6 siswa. Pengelompokan siswa tersebut diatur sesuai dengan nomor urut absen (kelompok sebelumnya). Setelah siswa dikelompokkan, maka guru membagikan soal kepada siswa dan siswa diwajibkan untuk menyelesaikan soal tersebut secara bersama-sama. Setelah 25 menit kemudian guru memberikan waktu kepada siswa tiap kelompok untuk menampilkan hasil kerjasama di depan kelas sambil mengadakan tanya jawab kepada siswa lainnya, kemudian jawab siswa dievaluasi oleh guru untuk mengetahui pengetahuan siswa mengenai materi FPB. Setelah itu, guru menguatkan siswa dengan cara membimbing siswadalam merumuskan kesimpulan menemukan konsep penyelesaian masalah.

\section{c. Pengamatan/observasi}

Dari hasil pengamatan pada siklus II, maka diperoleh data sebagai berikut:

1). Data hasil belajar siswa

Penilaian hasil belajar pada siklus II dilakukan melalui tes hasil belajar secara tertulis dan dilaksanakan setelah pembelajaran. Nilai hasil belajar siswa dapat dilihat pada tabel 4.2 berikut:

Tabel 4.2

Hasil tes belajar siswa pada siklus II

\begin{tabular}{|l|l|l|l|}
\hline No & Siswa & Nilai & Katagori \\
\hline
\end{tabular}




\begin{tabular}{|c|c|c|c|}
\hline 1 & Siswa 1 & 70 & Tuntas \\
\hline 2 & Siswa 2 & 80 & Tuntas \\
\hline 3 & Siswa 3 & Sakit & - \\
\hline 4 & Siswa 4 & 80 & Tuntas \\
\hline 5 & Siswa 5 & 80 & Tuntas \\
\hline 6 & Siswa 6 & 75 & Tuntas \\
\hline 7 & Siswa 7 & 70 & Tuntas \\
\hline 8 & Siswa 8 & 65 & Tuntas \\
\hline 9 & Siswa 9 & 80 & Tuntas \\
\hline 10 & Siswa 10 & Izin & - \\
\hline 11 & Siswa 11 & 75 & Tuntas \\
\hline 12 & Siswa 12 & 70 & Tuntas \\
\hline 13 & Siswa 13 & 75 & Tuntas \\
\hline 14 & Siswa 14 & 80 & Tuntas \\
\hline 15 & Siswa 15 & 70 & Tuntas \\
\hline 16 & Siswa 16 & 80 & Tuntas \\
\hline 17 & Siswa 17 & 60 & Belum Tuntas \\
\hline 18 & Siswa 18 & 75 & Tuntas \\
\hline 19 & Siswa 19 & 80 & Tuntas \\
\hline 20 & Siswa 20 & 70 & Tuntas \\
\hline 21 & Siswa 21 & 80 & Tuntas \\
\hline 22 & Siswa 22 & 70 & Tuntas \\
\hline 23 & Siswa 23 & 80 & Tuntas \\
\hline 24 & Siswa 24 & 75 & Tuntas \\
\hline 25 & Siswa 25 & 60 & Belum Tuntas \\
\hline 26 & Siswa 26 & 60 & Belum Tuntas \\
\hline 27 & Siswa 27 & 70 & Tuntas \\
\hline 28 & Siswa 28 & 75 & Tuntas \\
\hline 29 & Siswa 29 & 80 & Tuntas \\
\hline 30 & Siswa 30 & 75 & Tuntas \\
\hline 31 & Siswa 31 & 80 & Tuntas \\
\hline 32 & Siswa 32 & 80 & Tuntas \\
\hline \multicolumn{2}{|r|}{ Jumlah } & \multicolumn{2}{|l|}{2220} \\
\hline & Rata-rata & 74 & \\
\hline
\end{tabular}

Pada pembelajaran siklus II secara klasikal perolehan rata-rata hasil belajar siswa meningkat bila dibandingkan dengan kondisi pada siklus I. Perolehan nilai ratarata pada siklus II sebesar 74 yaitu dengan ketuntasan belajar secara klasikal 84,37\% yaitu 27 orang siswa dalam katagori tuntas, siswa yang belum mencapai batas ketuntasan sebanyak 3 orang siswa atau 9,37\% dikatagorikan belum tuntas, sedangkan 2 orang siswa $(6,25 \%)$ dikatakan belum memenuhi kriteria penilaian oleh peneliti 
karena kedua siswa tersebut tidak mengikuti proses pembelajaran atau sakit.

\section{d. Refleksi}

Berdasarkan hasil observasi yang dilakukan oleh peneliti pada siklus II, maka pelaksanaa pembelajaran dengan model Quantum Teaching dapat disimpulkan sebagai berikut:

1. Penyampaian materi dengan menggunakan model Quantum Teaching oleh guru dilakukan dengan lebih baik dan siswa lebih mudah memahaminya. Di samping itu, cara belajar dengan model Quantum Teaching telah dijelaskan dan diterapkan pada siklus I, sehingga mempermudah bagi siswa untuk mengikuti proses pembelajaran.

2. Suasana tempat belajar mulai kondusif dan proses belajar yang efektif dan menyenangkan

Perolehan nilai rata-rata pada siklus II sebesar 74 yaitu dengan ketuntasan belajar secara klasikal 84,37 \% yaitu 27 orang siswa dalam katagori tuntas, siswa yang belum mencapai batas ketuntasan sebanyak 3 orang siswa atau 9,37\% dikatagorikan belum tuntas, sedangkan 2 orang siswa $(6,25 \%)$ dikatakan belum memenuhi kriteria penilaian oleh peneliti karena kedua siswa tersebut tidak mengikuti proses pembelajaran atau sakit. Karena indikator keberhasilan belum tercapai, maka peneliti perlu melanjutkan penelitian pada siklus III.

\section{Siklus III}

Proses pembelajaran pada siklus III terdiri dari 4 tahap yaitu perencanaan, pelaksanaan, observasi dan refleksi.

\section{a. Perencanaan (Planning)}

Berdasarkan refleksi pada siklus II, Pada siklus III dilakukan perbaikanperbaikan agar aktivitas dan hasil belajar siswa dapat meningkat dengan melakukan identifikasi masalah. Langkah yang dilakukan selanjutnya adalah dengan membuat dan merevisi Rencana Pelaksanaan
Pembelajaran (RPP) yang mengacu pada pendekatan model Quatum Teaching. Guru membuat suasana kelas menjadi lebih nyaman dan ramai dengan membuat permainan atau nyanyi, Lembar Kerja Siswa (LKS), dan lembar observasi aktivitas siswa.

\section{b. Pelaksanaan (acting)}

Guru mempersiapkan materi pembelajaran dengan beberapa media belajar siswa dan lembaran kerja siswa (LKS) sesuai dengan RPP yang telah disusun. Guru mengulang lagi dan menjelaskan materi FPB dengan menyelesaikan soal-soal cerita kepada Siswa dengan seksama dan untuk mengetahui kemampuan siswa terhadap materi yang sebelumnya telah diberikan pada siklus II, guru memberikan pertanyaan kepada beberapa siswa secara random, kemudian mengelompokkan siswa dengan jumlah setiap kelompok sebanyak 5-6 siswa.

Hasil observasi yang dilakukan oleh peneliti, maka pelaksanaa pembelajaran dengan model Quantum Teaching pada siklus III dapat disimpulkan sebagai berikut:

1. Penyampaian materi dengan menggunakan model Quantum Teaching oleh guru dilakukan dengan sangat baik dan siswa telah mampu memahaminya. Di samping itu, model Quantum Teaching telah mempermudah siswa untuk mengikuti proses pembelajaran.

2. Suasana tempat belajar sangat kondusif dan sesama siswa sudah tercipta kebersamaan begitu juga dengan hubungan guru dengan siswa yang semakin akrap.

\section{c. Pengamatan/observasi}

1). Data hasil belajar siswa.

Dari hasil pengamatan Penilaian hasil belajar pada siklus III dilakukan melalui tes hasil belajar secara tertulis dan dilaksanakan setelah pembelajaran. Nilai hasil belajar siswa dapat dilihat pada tabel 4.3 berikut ini: 
Tabel 4.3

Hasil tes belajar siswa pada siklus III

\begin{tabular}{|c|c|c|c|}
\hline No & Siswa & Nilai & Katagori \\
\hline 1 & Siswa 1 & 100 & Tuntas \\
\hline 2 & Siswa 2 & 95 & Tuntas \\
\hline 3 & Siswa 3 & 60 & Belum Tuntas \\
\hline 4 & Siswa 4 & 80 & Tuntas \\
\hline 5 & Siswa 5 & 90 & Tuntas \\
\hline 6 & Siswa 6 & 90 & Tuntas \\
\hline 7 & Siswa 7 & 80 & Tuntas \\
\hline 8 & Siswa 8 & 60 & Belum Tuntas \\
\hline 9 & Siswa 9 & 80 & Tuntas \\
\hline 10 & Siswa 10 & 80 & Tuntas \\
\hline 11 & Siswa 11 & Alfa & - \\
\hline 12 & Siswa 12 & 90 & Tuntas \\
\hline 13 & Siswa 13 & 85 & Tuntas \\
\hline 14 & Siswa 14 & 85 & Tuntas \\
\hline 15 & Siswa 15 & 80 & Tuntas \\
\hline 16 & Siswa 16 & 80 & Tuntas \\
\hline 17 & Siswa 17 & 95 & Tuntas \\
\hline 18 & Siswa 18 & 100 & Tuntas \\
\hline 19 & Siswa 19 & 100 & Tuntas \\
\hline 20 & Siswa 20 & 95 & Tuntas \\
\hline 21 & Siswa 21 & 95 & Tuntas \\
\hline 22 & Siswa 22 & 90 & Tuntas \\
\hline 23 & Siswa 23 & 90 & Tuntas \\
\hline 24 & Siswa 24 & 80 & Tuntas \\
\hline 25 & Siswa 25 & Sakit & - \\
\hline 26 & Siswa 26 & 90 & Tuntas \\
\hline 27 & Siswa 27 & 85 & Tuntas \\
\hline 28 & Siswa 28 & 80 & Tuntas \\
\hline 29 & Siswa 29 & 90 & Tuntas \\
\hline 30 & Siswa 30 & 80 & Tuntas \\
\hline 31 & Siswa 31 & 85 & Tuntas \\
\hline 32 & Siswa 32 & 100 & Tuntas \\
\hline \multicolumn{2}{|c|}{ Jumlah } & \multicolumn{2}{|l|}{2590} \\
\hline & Rata-rata & 86,33 & \\
\hline
\end{tabular}

Pada pembelajaran siklus III, secara klasikal perolehan rata-rata hasil belajar siswa lebih meningkat bila dibandingkan dengan kondisi pada siklus II. Perolehan 
nilai rata-rata pada siklus III sebesar 86,33 dengan ketuntasan belajar siswa secara klasikal $87,5 \%$ yaitu 28 orang siswa dalam katagori tuntas, siswa yang belum mencapai batas ketuntasan individu sebanyak 2 orang siswa $(6,25 \%)$, sedangkan 2 orang siswa $(6,25 \%)$ dikatakan belum memenuhi kriteria penilaian oleh peneliti karena kedua siswa tersebut tidak mengikuti proses pembelajaran.

\section{d. Refleksi}

Berdasarkan hasil observasi siklus III, Pada pembelajaran siklus III, secara klasikal perolehan rata-rata hasil belajar siswa lebih meningkat bila dibandingkan dengan kondisi pada siklus II. Perolehan nilai rata-rata pada siklus III sebesar 86,33 dengan ketuntasan belajar siswa secara klasikal $87,5 \%$ yaitu 28 orang siswa dalam katagori tuntas, siswa yang belum mencapai batas ketuntasan individu sebanyak 2 orang siswa $(6,25 \%)$, sedangkan 2 orang siswa $(6,25 \%)$ dikatakan belum memenuhi kriteria penilaian oleh peneliti karena kedua siswa tersebut tidak mengikuti proses pembelajaran.. Karena indikator keberhasilan belajar siswa telah tercapai, maka penelitian ini dihentikan.

Dengan demikian, berdasarkan hasil penelitian yang dilakukan dalam tiga siklus (tiga kali pertemuan) dapat dikatakan bahwa pembelajaran dengan model Quantum Teaching sudah tuntas karena ketuntasan belajar siswa kelas IV SD Negeri Sindangwasa Kecamatan Palasah kabupaten majalengka. Berdasarkan indikator keberhasilan siswa diperoleh kesimpulan bahwa aktivitas siswa pada siklus III dapat dikatagori tuntas karena hasil akhir aktivitas siswa mendapatkan skor $\geq 65$ dari sekurangkurangnya $85 \%$ dari keseluruhan jumlah siswa.

\section{KESIMPULAN DAN SARAN}

Berdasarkan hasil penelitian dan hasil pembahasan data secara deskriptif diperoleh kesimpulan sebagai berikut:

1. Penerapan model Quantum Teaching pada materi FPB dapat meningkatkan hasil belajar siswa kelas IV SD NegeriSindangwasa Kecamatan Palasah kabupaten Majalengka. Pada siklus 1 memperoleh nilai rata-rata 68,88 dengan ketuntasan secara klasikal $65,62 \%$ yaitu 21 siswa katagori tuntas, 6 siswa $(18,75 \%)$ dikatagorikan belum tuntas dan 5 siswa $(15,62 \%)$ belum memenuhi kriteria penilaian karna tidak hadir, pada siklus ke II sudah mengalami peningkatan dengan nilai rata-rata 74 , dengan ketuntasan secara klasikal 84,37 yaitu 27 siswa katagori tuntas, 3 siswa $(9,38 \%)$ belum tuntas dan 2 siswa $(6,25 \%)$ belum memenuhi kriteria penelaian karna tidak hadir atau sakit, sedangkan pada siklus III juga sudah mengalami peningkatan dibandingkan pada siklus II dengan nilai rata-rata 86,3 dengan ketuntasan secara klasikal $(87,5 \%)$ yaitu 28 siswa dalam katagori tuntas, 2 siswa $(6,25 \%)$ belum tuntas dan 2 siswa $(6,25 \%)$ belum memenuhi kriteria penilaian karna tidak mengikuti proses penilaian.

2. Meningkatnya hasil belajar siswa kelas IV SD NegeriSindangwasa Kecamatan Palasah kabupaten Majalengka Ajaran 2014/2015 pada materi FPB, hal ini terlihat dari data nilai tes siswa setiap siklus. ( Terlampir)

Berdasarkan kesimpulan di atas, saran-saran yang dapat peneliti berikan adalah sebagai berikut:

1. Untuk meningkatkan hasil belajar hendaknya guru menggunakan model Quantum Teaching pada pelajaran matematika sangat sesuai hal tersebut dapat dibuktikan dari hasil pengamatan guru terhadap hasil belajar siswa baik 
pada siklus I, II dan III yang terus meningkat. Hal ini dapat dilakukan dengan menerapkan metode-metode pebelajaran yang membuat matematika tidak membosankan.

2. Diharapkan kepada peneliti berikutnya agar dapat melakukan penelitian yang sejenis dalam topik yang lain serta pembahasan yang lebih luas.

\section{DAFTAR PUSTAKA}

Arikunto, Suharsimi,dkk. 2006. Penelitian Tindakan Kelas. Jakarta: Bumi Aksara.

Arikunto, S. (2013). Prosedur Penelitian suatu pendekatan Praktik. Jakarta: Rineka Cipta.

Depdiknas. (2006). Panduan Penyusunan Kurikulum Tingkat Satuan Pendidikan. Badan Standar Nasional Pendidikan: Jakarta.

Dimyati, Mudjiono. 2009. Belajar dan Pembelajaran. Jakarta: Rineka Cipta.

Djamarah, Bahri Syaiful. 2002. Psikologi Belajar, Jakarta: Rineka Cipta.

Hamalik, Oemar, 2008. Kurikulum Dan Pembelajaran. Jakarta: Bumi Aksara.
Nilandri. A, 2005. Quantum Teaching: Orchestrating Student Succes (Bobbi DePoter, Mark Reardon, Sarah Singer Nourie, Terjemahan), Boston allyn and Bacon. Buku Asli di terbitkan tahun 1999.

Soedjadi, R. 2000. Kiat Pendidikan Matematika di Indonesia. Jakarta: Departemen Pendidikan Nasional Pendidikan Indonesia.

Sudjana, N. (2010). Penilaian Hasil Proses Belajar Mengajar. Bandung: Remaja Rosdakarya.

Sudjana. 2004. Dasar-Dasar Proses Belajar Mengajar. Bandung: Sinar Baru Algensindo

Suherman, Erman dan Udin S. Winataputra 2000. Strategi Mengajar Matematika. Jakarta: Universitas Terbuka.

Tim Bina Karya Guru. 2007. Terampil Berhitung Matematika untuk SD Kelas 4. Jakarta: Erlangga.

Tirtonegoro, S. (2001). Anak Supernormal dan Program Pendidikannya. Yogyakarta: Bumi Aksara. 